\title{
The Role of Water Content and Paste Proportion on Physico- mechanical Properties of Alkali Activated Fly Ash-Ggbs Concrete
}

\author{
Raffaele Vinai $^{1}$ (I) $\cdot$ Ali Rafeet $^{1} \cdot$ Marios Soutsos $^{1} \cdot$ Wei Sha $^{1}$
}

Published online: 23 October 2015

(C) The Minerals, Metals \& Materials Society (TMS) 2015

\begin{abstract}
The growth of the construction industry worldwide poses a serious concern on the sustainability of the building material production chain, mainly due to the carbon emissions related to the production of Portland cement. On the other hand, valuable materials from waste streams, particularly from the metallurgical industry, are not used at their full potential. Alkali-activated concrete (AAC) has emerged in the last years as a promising alternative to traditional Portland cement-based concrete for some applications. However, despite showing remarkable strength and durability potential, its utilisation is not widespread, mainly due to the lack of broadly accepted standards for the selection of suitable mix recipes fulfilling design requirements, in particular workability, setting time and strength. In this paper, a contribution towards the design development of AAC synthesised from pulverised fuel ash $(60 \%)$ and ground granulated blast furnace slag (ggbs) $(40 \%)$ activated with a solution of sodium hydroxide and sodium silicate is proposed. Results from a first batch of mixes indicated that water content influences the setting time and that paste content is a key parameter for controlling strength development and workability. The investigation indicated that, for the given raw materials and activator compositions, a minimum water-to-solid (w/s) ratio of 0.37 was needed for an initial setting time of about $1 \mathrm{~h}$. Further work with paste content in the range of $30-33 \%$ determined the relationship between workability
\end{abstract}

The contributing editor for this article was Yiannis Pontikes.

Raffaele Vinai

r.vinai@qub.ac.uk

1 School of Planning, Architecture and Civil Engineering, Queen's University Belfast, Belfast BT9 5AG, UK and strength development and w/s ratio and paste content. Strengths in the range of 50-60 MPa were achieved.

Keywords Alkali-activated concrete $\cdot$ Mix design . Setting time $\cdot$ Slag valorisation $\cdot$ Activated slag

\section{Introduction}

The worldwide annual production of cement is estimated to be about 4 billion tonnes [1], whereas the building sector is estimated to consume more than $40 \%$ of global energy [2]. The construction industry represents about $8.8 \%$ of Gross Domestic Product and $29 \%$ of industrial employment, and had a turnover of 92.5 billion euros in 2013 in EU28 [3], and therefore it could offer the possibility of absorbing high volume of waste and by-products, in particular slags produced by metallurgical industry, if reliable and efficient recycling strategies for their use as construction materials are available. This would allow not only the reutilisation of slags (and the consequent benefit in terms of environmental impact of the whole value chain) but also the avoidance of the emissions related to the production of Portland cement (PC), which are estimated to represent about $8 \%$ of the worldwide carbon emissions [4]. Ground granulated blast furnace slag (ggbs) is a by-product from the production of iron which has enormous potential for being used as a binder in concrete. Although already used with PC in traditional concrete, its utilisation for the development of PCfree concrete by alkali activation of aluminosilicate precursors is gaining attention [5]. The chemistry on which the reaction of these materials is based differs significantly from that of PC, and no broadly accepted methodology for the development of mix design guidelines that allow the control of fresh and hardened properties is available in the technical literature. 
Literature on alkali-activated materials is vast and comprehensive reviews have been compiled and made available in recent years. An up-to-date picture of the research development, achieved milestones and perspectives for the future of the alkali-activated materials is presented in [6]. Alkali-activated concrete (AAC) is currently commercialised in USA, Australia, India, UK and the Netherlands, and patents [7, 8] have been issued for such material (often also referred to as 'geopolymer concrete'). Studies focused on fly ash concrete [9-13] indicated that the parameters influencing the properties of fly ash-based concrete are mainly dosages of activators, waterto-solid ratio (w/s), curing temperature (in the range of $60-100{ }^{\circ} \mathrm{C}$ ) and its duration, along with physical properties of precursor material. Reinforced concrete structural elements such as beams and columns were reported to have elastic and strength properties similar to those of PC concretes $[14,15]$. Slag-based AACs were also compared with PC-based concrete [16, 17], showing that at similar binder content and water/binder ratio, the compressive strength for alkali-activated slag concrete cured at ambient temperature $\left(20^{\circ} \mathrm{C}\right)$ was higher at both 28 and 90 days than that of PC [17]. The quick setting of slag-rich mixes has been highlighted in the literature without pointing out solutions to tackle this issue. Examples can be found in the available literature on fly ash blended with slag to produce AAC [18-22]. Whilst compressive strength was found to increase with the increase in slag content, a decrease of the workability, attributed to the accelerated reaction of the calcium and the angular shape of slag particles, was observed. Setting time was also reported to decrease as the amount of slag increased. Maximum slag proportion (as partial replacement of fly ash) suggested from the literature was 15-20\% [19], with some authors proposing up to $30 \%$ [22]. Technical issues such as setting time and workability were highlighted in alkali-activated slag and fly ash/slag systems.

In this study, a blend of $60 \%$ pulverised fuel ash (pfa) and $40 \%$ ggbs was used for concrete production. The objective of this study was to analyse the effects of binder content, paste content and water-to-solid ratio on fresh and hardened properties of the concrete.

\section{Materials and Methods}

Pfa was supplied by Power Minerals Ltd., Drax Power Station, North Yorkshire, UK. X-ray diffraction was carried out using pure copper-K-Alpha 1 radiation with wavelength $1.54 \AA$. The X-ray generator was set to $40 \mathrm{kV}$ and $40 \mathrm{~mA}$, and the recorded angular range was 5 to $70^{\circ}$ $(2 \theta)$ with a step close to $0.017^{\circ}$. A quantitative estimation of the amorphous and crystalline fractions was carried out by applying the Rietveld method, adding and blending $20 \%$ in weight of corundum $\left(\mathrm{Al}_{2} \mathrm{O}_{3}\right)$ as internal standard. The amorphous content was $86 \%$, whereas quartz (4.6\%), mullite $(8.1 \%)$, haematite $(0.5 \%)$ and magnetite $(0.8 \%)$ were the main crystalline phases detected. Ggbs was supplied by Civil and Marine Ltd-Hanson Company and member of the HeidelbergCement Group, West Thurrock, Essex, UK. Akermanite and gehlenite in crystalline state were detected by X-ray diffraction, whereas the amorphous content was $>95 \%$.

$\mathrm{X}$-ray fluorescence (XRF) analysis was carried out on a fuse bead sample, which is a technique for removing both grain size and mineralogical effects. The procedure consists of heating the sample in the presence of air at high temperature $\left(1000-1200{ }^{\circ} \mathrm{C}\right)$ in a platinum crucible with lithium borates. This process converts metals and salts to oxides. Results are therefore shown in terms of oxides in their final form. For example, iron oxides detected by XRF are reported as $\mathrm{Fe}_{2} \mathrm{O}_{3}$, whereas crystalline phases identified with XRD in pfa were $\mathrm{Fe}_{2} \mathrm{O}_{3}$ as well as $\mathrm{Fe}_{3} \mathrm{O}_{4}$. Main oxide compositions of the raw materials are shown in Table 1 , whereas Table 2 shows their physical properties.

Commercial chemicals were used for activating the raw materials, namely solid $\mathrm{NaOH}$ of commercial grade $(99 \%$ purity) and sodium silicate solution with $\mathrm{SiO}_{2}: \mathrm{Na}_{2} \mathrm{O}$ molar ratio $=2.055$. Mass composition of the commercial sodium silicate solution, provided by Fisher Scientific, was $\mathrm{Na}_{2} \mathrm{O} 12.8 \%, \mathrm{SiO}_{2} 25.5 \%$ and water $61.7 \%$, in weight.
Table 1 Chemical components (oxides, mass percentage) as per $\mathrm{XRF}$ analysis

\begin{tabular}{lrr}
\hline Component & \multicolumn{1}{c}{ pfa } & \multicolumn{1}{c}{ ggbs } \\
\hline $\mathrm{Na}_{2} \mathrm{O}$ & 0.89 & 1.05 \\
$\mathrm{MgO}$ & 1.33 & 6.94 \\
$\mathrm{Al}_{2} \mathrm{O}_{3}$ & 22.52 & 11.23 \\
$\mathrm{SiO}_{2}$ & 46.78 & 29.38 \\
$\mathrm{P}_{2} \mathrm{O}_{5}$ & 0.17 & 0.00 \\
$\mathrm{SO}_{3}$ & 0.90 & 1.76 \\
$\mathrm{Cl}_{\mathrm{K}}$ & 0.00 & 0.01 \\
$\mathrm{~K}_{2} \mathrm{O}$ & 4.09 & 0.93 \\
$\mathrm{CaO}$ & 2.24 & 43.72 \\
$\mathrm{TiO}_{2}$ & 1.05 & 0.67 \\
$\mathrm{~V}_{2} \mathrm{O}_{5}$ & 0.08 & 0.01 \\
$\mathrm{Cr} \mathrm{O}_{3}$ & 0.03 & 0.02 \\
$\mathrm{MnO}$ & 0.05 & 0.51 \\
$\mathrm{Fe} \mathrm{O}_{3}$ & 9.15 & 0.36 \\
$\mathrm{CoO}$ & 0.02 & 0.00 \\
$\mathrm{NiO}$ & 0.02 & 0.00 \\
$\mathrm{CuO}$ & 0.02 & 0.00 \\
$\mathrm{ZnO}$ & 0.06 & 0.00 \\
$\mathrm{SrO}$ & 0.04 & 0.07 \\
$\mathrm{BaO}$ & 0.10 & 0.12 \\
$\mathrm{LOI}$ & 3.57 & 2.40 \\
\hline & &
\end{tabular}


Table 2 Physical properties of precursor materials

\begin{tabular}{llll}
\hline Parameter & u.o.m. & pfa & ggbs \\
\hline Volumetric mass density & $\mathrm{g} / \mathrm{cm}^{3}$ & 2.42 & 2.92 \\
Grain size range & $\mu \mathrm{m}$ & $0.24-88.00$ & $0.24-149.00$ \\
$\mathrm{~d} 50$ & $\mu \mathrm{m}$ & 18 & 19 \\
Amorphous content & $\mathrm{wt} \%$ & 86 & $>95$ \\
\hline
\end{tabular}

$\mathrm{NaOH}$ solution was prepared by dissolving solid $\mathrm{NaOH}$ in tap water. Molar concentration was $10 \mathrm{M}$, corresponding to $30 \%$ in wt $\%$ ( $300 \mathrm{~g}$ of $\mathrm{NaOH}$ dissolved in $700 \mathrm{~g}$ of tap water). The dosage of the activators in the mix was described by the alkali dosage $(\mathrm{M}+)$ and the alkali modulus (AM). $\mathrm{M}+$ is defined as the mass ratio of total sodium oxide $\left(\mathrm{Na}_{2} \mathrm{O}\right)$ in the activating solution (i.e. $\mathrm{Na}_{2} \mathrm{O}$ from sodium hydroxide solution $+\mathrm{Na}_{2} \mathrm{O}$ from sodium silicate solution) to the binder (dry mass of pfa + ggbs):

$\mathrm{M}+=\frac{\mathrm{Na}_{2} \mathrm{O}}{\text { pfa }+ \text { ggbs }}$ (mass)

Alkali modulus (AM) is the mass ratio of sodium oxide to silica in the activating solution:

$\mathrm{AM}=\frac{\mathrm{Na}_{2} \mathrm{O}}{\mathrm{SiO}_{2}}$ (mass)

In the literature, silica modulus is often used, i.e. the ratio $\mathrm{SiO}_{2} / \mathrm{Na}_{2} \mathrm{O}$, which corresponds to $1 / \mathrm{AM}$. Either mass ratio or molar ratio can be used. The mass ratio approach was followed in this research, as it was more convenient for calculating the quantities of chemicals in the mix.

A previous study on the effect of chemical dosages on the reaction development for low Ca system (100\% pfa) and high Ca system (30\% pfa and $70 \%$ ggbs) indicated that strength increases with the increase of the AM and then it decreases until a residual value, presumably due to the reduced amount of available silica that needs to be involved in the 'reorganisation-gelation-polymerisation' steps of the geopolymer formation. The optimum value of AM was found in the range $0.95-1.25$. The effect of the $\mathrm{M}+$ increase was also associated with an increase in the compressive strength, but the incremental gain narrowed when $\mathrm{M}+$ was higher than $9.5 \%$ for pure pfa system and higher than $7.5 \%$ for high ggbs content systems. Higher dosages were found to be detrimental also for the triggering of fast setting behaviour. In order to ensure proper strength development, initial setting time and also considering that high dosages imply high production costs, alkali dosages were fixed at $\mathrm{M}+=7.5 \%$ and $\mathrm{AM}=1.25$. Some details can be found in [23].

The water/solids ratio is defined as the ratio between total mass of water (i.e. tap water + water in the alkali solutions) and the total solid mass (i.e. mass of binder + mass of alkali solids). Crushed basalt of two sizes (4/10 and 10/20 $\mathrm{mm}$ ) and Lough sand $(0 / 4 \mathrm{~mm})$ were used as aggregates in the following proportions (in volume): $40 \%$ sand over total aggregate, ratio between coarse aggregate sizes equal to $40 \% / 60 \%$ for $4 / 10 \mathrm{~mm}$ and $10 / 20 \mathrm{~mm}$. The grain size distribution of the aggregate mix is shown in Fig. 1. Aggregates were first oven-dried at $105{ }^{\circ} \mathrm{C}$ overnight for avoiding the inclusion of unknown water mass in the system. Subsequently, they were wetted with a mass of water calculated according to their 1-h absorption rate (Table 3), bringing them to saturated-surface-dry condition. The aim of this operation was to avoid aggregate to absorb water that should be available for the lubrication and for the chemical reaction of the system. The water used for the saturation of the aggregate was not considered in the overall water/solid ratio. Bulk density of the aggregate mix has been measured with a 71 container in a loose and vibrated state. Void contents in the two states were calculated accordingly and results are shown in Table 4.

The composition of the concrete, in terms of volumes of its constituents, is shown in Fig. 2. Binder content is defined as the mass of solid precursors ( $\mathrm{pfa}+\mathrm{ggbs}$ ) per cubic metre of concrete. Paste volume is defined as the volume of the solid precursor + activating solutions + added water, per cubic metre of concrete. Paste content is defined as the percentage of paste volume over the total concrete volume.

Mixes were prepared according to the mix proportion reported in Table 5. 100-mm cube concrete samples were cast for compressive strength measurement. Samples were cured in plastic boxes ( $>90 \%$ relative humidity) and kept

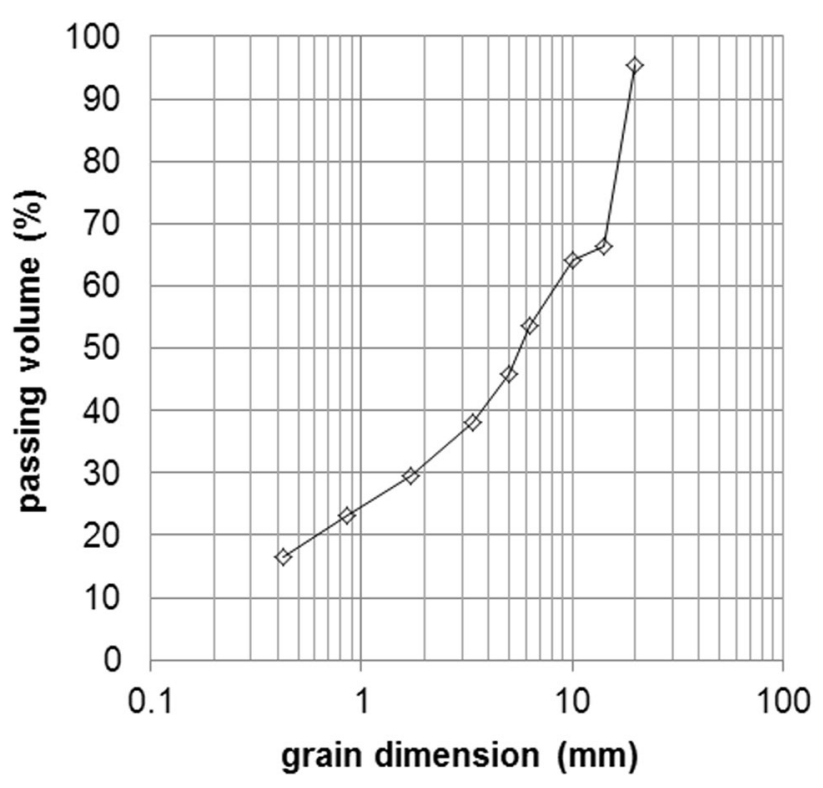

Fig. 1 Aggregate particle size distribution 
Table 3 Physical properties of aggregates

\begin{tabular}{lll}
\hline Material name & Particle density on an oven-dried basis $\left(\mathrm{t} / \mathrm{m}^{3}\right)$ & 1-h water absorption $(\%)$ \\
\hline Sand $0 / 4$ & 2.69 & 0.92 \\
Crushed basalt $4 / 10$ & 2.79 & 1.45 \\
Crushed basalt $10 / 20$ & 2.75 & 1.24 \\
\hline
\end{tabular}

Table 4 Void content of aggregate mix

\begin{tabular}{lll}
\hline Packing condition & Bulk density $\left(\mathrm{kg} / \mathrm{m}^{3}\right)$ & Void content $(\%)$ \\
\hline Loose & 1797.5 & 34.3 \\
Vibrated & 2125.8 & 22.3 \\
\hline
\end{tabular}

at $20{ }^{\circ} \mathrm{C}$ throughout the curing period. Curing temperature was ensured by the setting of the curing room, whereas relative humidity in plastic boxes was checked regularly through a portable digital humidity reader positioned inside one of the boxes. Three cubes were tested in compression at each designated time (1, 7 and 28 days). Average strength and standard deviation were calculated. A 2000
$\mathrm{kN}$ capacity compression testing machine (Samuel Denison Ltd.) was used for all testing with a loading rate of $3.33 \mathrm{kN} /$ $\mathrm{s}$, within the range specified in BS 1881-116:1983 [24]. Measurement of the initial and final setting time was carried out on mortars. The method described in BS EN 196-3 involving the use of the Vicat apparatus on paste was not suitable, since the water content necessary for achieving the required paste consistency was too low resulting in short setting times. This method was also not applicable for mortars since sand grains may interfere with the penetration depth of the needle. The procedure described in the American Society for Testing and Materials (ASTM) standard C403M-08 - Standard Test Method for Time of Setting of Concrete Mixtures by Penetration Resistance [25] — was considered more suitable for the assessment of
Fig. 2 Composition of alkaliactivated concretes

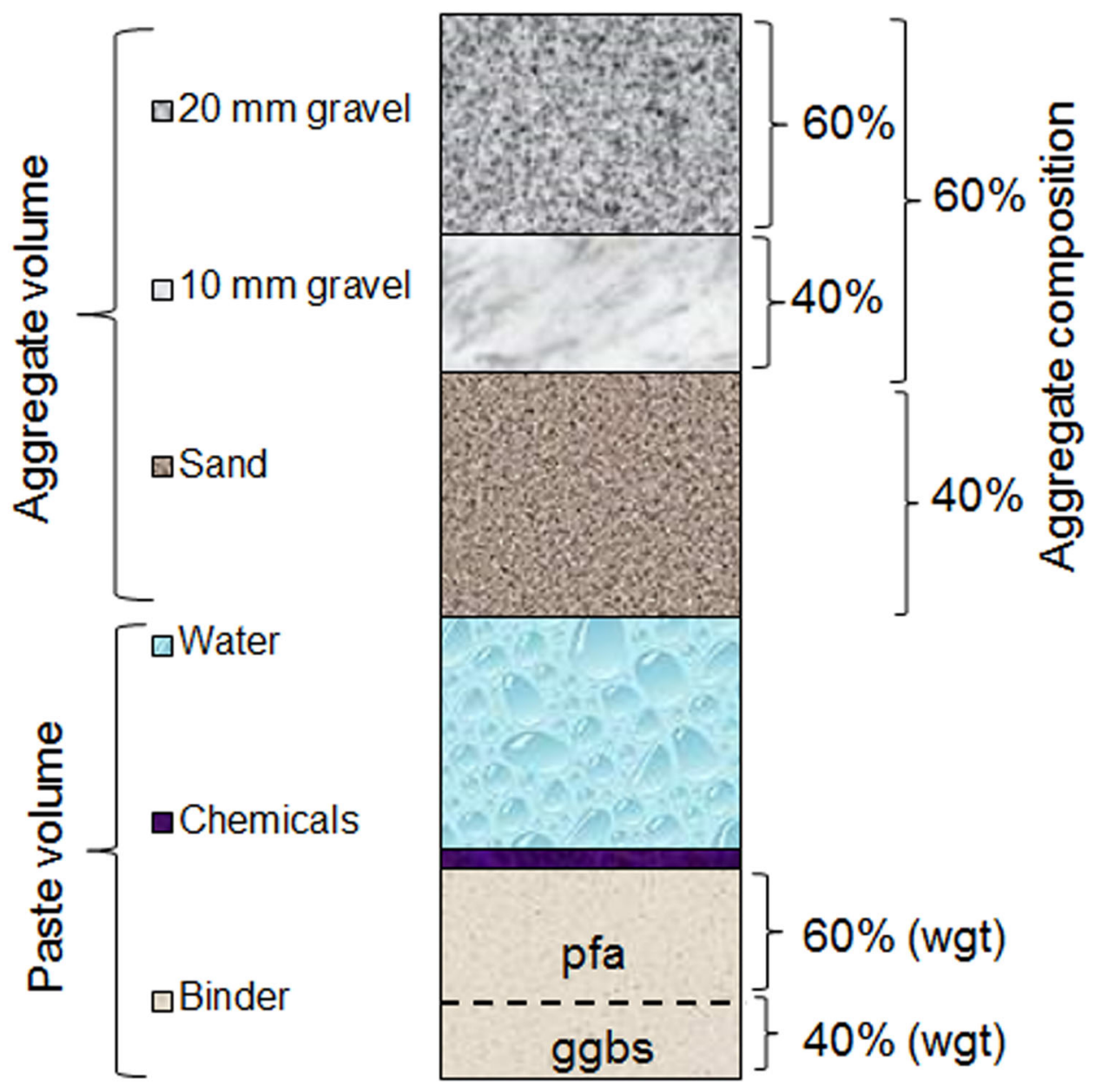


Table 5 Mixes design, quantities in $\mathrm{kg}$ (for the production of $1 \mathrm{~m}^{3}$ of concrete)

\begin{tabular}{|c|c|c|c|c|c|c|c|c|}
\hline $\begin{array}{l}\text { Mix } \\
\text { label }\end{array}$ & pfa & ggbs & $\begin{array}{l}\text { Sodium silicate } \\
\text { solution }\end{array}$ & $\begin{array}{l}\text { Sodium hydroxide } \\
\text { solution }\end{array}$ & Water & $\begin{array}{l}\text { Sand } \\
0 / 4 \mathrm{~mm}\end{array}$ & $\begin{array}{l}\text { Crushed basalt } \\
4 / 10 \mathrm{~mm}\end{array}$ & $\begin{array}{l}\text { Crushed basalt } \\
10 / 20 \mathrm{~mm}\end{array}$ \\
\hline $\mathrm{C} 1$ & 308 & 206 & 121 & 99 & 75 & 615 & 385 & 550 \\
\hline $\mathrm{C} 2$ & 300 & 200 & 118 & 97 & 30 & 670 & 430 & 600 \\
\hline C3 & 270 & 180 & 106 & 87 & 65 & 670 & 430 & 600 \\
\hline $\mathrm{C} 4$ & 240 & 160 & 94 & 77 & 55 & 720 & 450 & 660 \\
\hline C5 & 210 & 140 & 82 & 68 & 50 & 760 & 480 & 690 \\
\hline C6 & 210 & 140 & 82 & 68 & 60 & 750 & 470 & 685 \\
\hline $\mathrm{C} 7$ & 240 & 160 & 94 & 77 & 70 & 710 & 430 & 640 \\
\hline C8 & 270 & 180 & 106 & 87 & 50 & 690 & 420 & 630 \\
\hline C9 & 240 & 160 & 94 & 77 & 45 & 730 & 460 & 660 \\
\hline C10 & 210 & 140 & 83 & 67 & 80 & 730 & 460 & 660 \\
\hline C11 & 249 & 166 & 98 & 80 & 40 & 721 & 450 & 661 \\
\hline $\mathrm{C} 12$ & 239 & 159 & 94 & 77 & 52 & 721 & 450 & 661 \\
\hline C13 & 230 & 153 & 90 & 74 & 63 & 721 & 450 & 661 \\
\hline $\mathrm{C} 14$ & 227 & 151 & 89 & 73 & 66 & 721 & 450 & 661 \\
\hline C15 & 218 & 145 & 86 & 70 & 76 & 721 & 450 & 661 \\
\hline C16 & 219 & 146 & 86 & 70 & 56 & 742 & 464 & 681 \\
\hline $\mathrm{C} 17$ & 216 & 144 & 85 & 69 & 59 & 742 & 464 & 681 \\
\hline C18 & 213 & 142 & 84 & 69 & 62 & 742 & 464 & 681 \\
\hline C19 & 209 & 139 & 82 & 67 & 57 & 753 & 470 & 690 \\
\hline C20 & 203 & 136 & 80 & 65 & 63 & 753 & 470 & 690 \\
\hline C21 & 198 & 132 & 78 & 64 & 69 & 753 & 470 & 690 \\
\hline
\end{tabular}

the setting time of mortars. A manual penetrometer, consisting of a spring loaded device graduated from 1 to 100 dekanewton $(\mathrm{daN})$, coupled with needles of different print areas $\left(650-16 \mathrm{~mm}^{2}\right)$, was used. The initial setting time is conventionally read from the experimental curves when a pressure of $3.45 \mathrm{MPa}$ is reached, whereas the final setting time is read when a pressure of $27.6 \mathrm{MPa}$ is required for the needle penetration.

\section{Results and Discussion}

\section{Phase 1: Effect of Binder Content and w/s Ratio on Strength and Workability}

In phase 1 , a preliminary analysis of the effects of binder content and w/s ratio on workability and strength development was carried out, varying the binder content in the range $350-514 \mathrm{~kg} / \mathrm{m}^{3}$ and the $\mathrm{w} / \mathrm{s}$ ratio in the range $0.30-0.45$. A spreadsheet was developed for the calculation of the quantities for cubic metre of activating solutions, added water and aggregate for each combination of binder content (i.e. mass of solid precursor pfa + ggbs) and w/s ratio. The aim was the understanding of the main trends and the assessment of preliminary reference values for fresh and hardened properties. Ten mixes (labelled $\mathrm{C} 1$ to
C10, Tables 5 and 6) were cast for phase 1. Table 6 summarises the mix parameters. Some mixes were unsuccessful: C2 set in the mixer; C5 was too dry and only 6 cubes were cast; $\mathrm{C} 9$ was too dry and no cubes were cast. Measured compressive strength and slump fall are shown in Figs. 3 and 4, respectively.

The following observations can be made from the results:

(a) As expected, the higher the binder content, the higher the compressive strength at 28 days. The only exception was the mix with the highest binder content $\left(514 \mathrm{~kg} / \mathrm{m}^{3}\right)$, which had a lower strength at all the three testing ages compared to the ones with binder contents of 400 and $450 \mathrm{~kg} / \mathrm{m}^{3}$. A possible explanation could be the high paste proportion (higher than $43 \%$ ) which might have led to segregation of the aggregate. The final strength may therefore have been affected by an uneven aggregate distribution in the matrix. This phenomenon is related mainly to the viscosity of the paste, the grading of the aggregate (in particular the amount of fine fraction) and the vibration procedure. Higher relative volume of fine aggregate, higher viscosity of paste and shorter vibration time could result in a reduction of the segregation effects on samples with high paste volume. 
Table 6 Phase 1 mix proportions, uniaxial compressive strength (UCS) and standard deviations (in bracket)

\begin{tabular}{|c|c|c|c|c|c|c|c|}
\hline Label & Binder cont. $\left(\mathrm{kg} / \mathrm{m}^{3}\right)$ & w/s ratio & Paste volume $(\%)$ & UCS 1 day (MPa) & UCS 7 days (MPa) & UCS 28 days (MPa) & Slump (mm) \\
\hline $\mathrm{C} 1$ & 514 & 0.37 & 43.4 & $12.2(1.1)$ & $41.8(1.6)$ & $61.8(1.7)$ & 280 \\
\hline $\mathrm{C} 2$ & 500 & 0.30 & 37.9 & - & - & - & - \\
\hline $\mathrm{C} 3$ & 450 & 0.37 & 37.9 & $14.6(0.4)$ & $49.0(2.3)$ & $70.4(0.1)$ & 280 \\
\hline $\mathrm{C} 4$ & 400 & 0.37 & 33.4 & $8.2(0.1)$ & $44.9(0.7)$ & $69.1(1.4)$ & 220 \\
\hline $\mathrm{C} 5$ & 350 & 0.37 & 29.4 & $2.8(0.3)$ & $35.1(1.5)$ & - & 10 \\
\hline $\mathrm{C} 6$ & 350 & 0.40 & 30.4 & $4.0(0.1)$ & $38.5(1.0)$ & $60.4(0.4)$ & 35 \\
\hline $\mathrm{C} 7$ & 400 & 0.40 & 34.9 & $14.7(0.5)$ & $42.3(1.8)$ & $66.7(1.1)$ & 260 \\
\hline $\mathrm{C} 8$ & 450 & 0.34 & 36.4 & $15.3(1.7)$ & $47.0(0.8)$ & $72.3(1.4)$ & 190 \\
\hline C9 & 400 & 0.34 & 32.4 & - & - & - & - \\
\hline $\mathrm{C} 10$ & 350 & 0.45 & 32.4 & $3.4(0.5)$ & $33.2(1.0)$ & $56.1(1.7)$ & 155 \\
\hline
\end{tabular}



Fig. 3 Compressive strength development for concretes from phase 1

(b) Binder content of $450 \mathrm{~kg} / \mathrm{m}^{3}$ led to the highest strength (around $72 \mathrm{MPa}$ after 28 days). An increase in the w/s ratio from 0.34 to 0.37 seemed to result in a decrease in strength at 28 days, although such decrease was very small. The same trend was observed for the $400 \mathrm{~kg} / \mathrm{m}^{3}$ binder content.

(c) Slump fall was higher than $190 \mathrm{~mm}$ when binder content was higher than $350 \mathrm{~kg} / \mathrm{m}^{3}$, even for w/s ratio as low as 0.34 . For low binder content $(350 \mathrm{~kg} /$ $\mathrm{m}^{3}$ ), slump values lower than $50 \mathrm{~mm}$ were recorded for w/s ratios up to 0.40 .

(d) Mixes with low w/s ratios set very quickly. When a w/s $=0.30$ was used ( $\operatorname{mix} \mathrm{C} 2$ ), casting was not possible as the mix set in the mixer bowl. It can be concluded that the reduction of $\mathrm{w} / \mathrm{s}$ ratio is

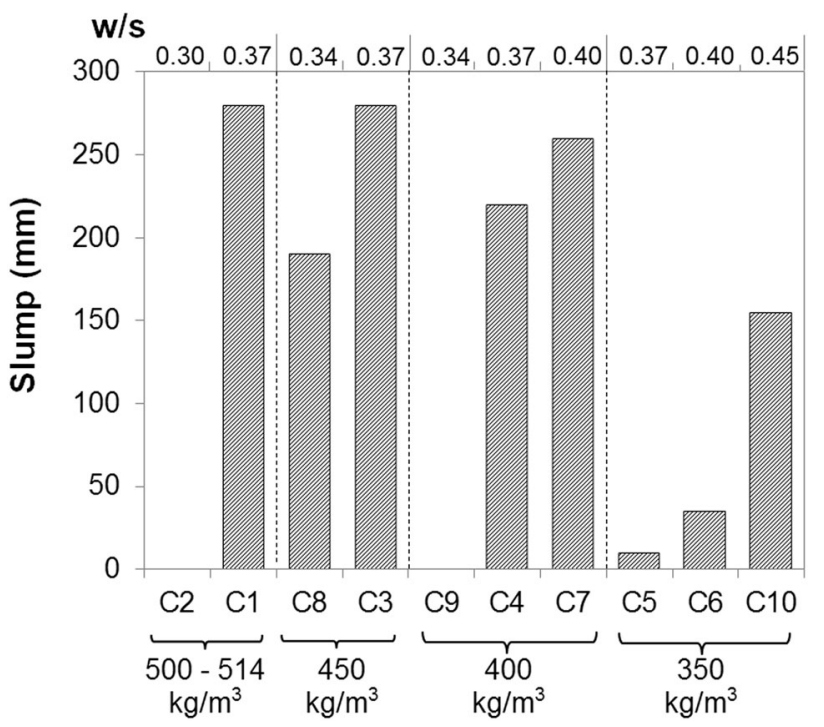

Fig. 4 Slump measurements for concretes from phase 1

not always an option for controlling the workability of the mixes, as it can result in short setting times.

(e) Some of the mixes were too dry for proper casting (C5, C9) of cubes. In the case of C5, a paste volume of $29.4 \%$ resulted in a mix that was difficult to cast and only 6 cubes were successfully compacted/cast. The w/s ratio of $0.37 \mathrm{did}$ not present any problems with other mixes of higher paste volume. C9 proved very difficult to compact and no cubes were cast. This is believed to have been due to the combined effect of paste content and relatively low w/s ratio. The w/s ratio of 0.34 might have been low for this mix but it was satisfactory for mixes with higher paste contents, e.g. $36.4 \%$ for mix $\mathrm{C} 8$. 
(f) Increasing the binder content from 350 to $450 \mathrm{~kg} / \mathrm{m}^{3}$ resulted in a strength increase of about $14 \mathrm{MPa}$. However, the strength of $60 \mathrm{MPa}$ was also achievable with lower binder contents.

(g) w/s ratio effect on strength was moderate (reduction of about $2 \mathrm{MPa}$ ) for values as low as 0.40 . For higher $\mathrm{w} / \mathrm{s}$ ratios, the strength decrease was more pronounced.

(h) When plotting the workability and strength data versus the paste proportion, it is possible to define a range of paste volume (30-33\%) in which compressive strength is close to the highest possible whilst having a desired workability (see Fig. 5).

\section{Effect of w/s Ratio on Initial Setting Time}

Following the experiments described above, an investigation on the effect of w/s ratio on setting time was carried out. Five mortars were prepared with the same binder blend $(60 / 40 \mathrm{pfa} / \mathrm{ggbs})$ and the same activator dosages $(\mathrm{M}+7.5 \%$, AM 1.25) of the investigated concrete, keeping a fixed sand content of $1375 \mathrm{~kg} / \mathrm{m}^{3}$ which resulted in a paste content of $48.9 \%$. The w/s ratio was varied in the range $0.33-0.42$. Mortar samples were tested according to the method described in "Materials and Methods" section. Results are shown in Fig. 6. It can be seen that the initial setting time is noticeably affected by the w/s ratio of the mortar: the higher the $\mathrm{w} / \mathrm{s}$ ratio, the longer the initial setting time. Figure 7 summarises the results and shows the relationship between initial setting time and w/s ratio. This diagram was plotted using data in Fig. 6, specifically the times corresponding to the initial setting time pressure. It can therefore be concluded that a $\mathrm{w} / \mathrm{s}$ ratio above a certain minimum is necessary for ensuring the initial setting time required for the specific application (e.g. 0.37 for setting time of about $60 \mathrm{~min}$ ).

\section{Phase 2: Effect of Paste Volume Proportion and w/s Ratio on Strength and Workability}

Following the results described above, in order to improve our understanding of factors affecting fresh and hardened properties of $\mathrm{AAC}$, a further 11 mixes of $60 / 40 \mathrm{pfa} / \mathrm{ggbs}$ blend were investigated, focusing on paste proportion in the range of 30-33\%. Details of the mixes for this second phase are shown in Tables 5 and 7. The w/s ratio 0.33 (C11) proved not to be sufficient for the preparation of concrete with $33 \%$ paste proportion, since the mix set in the drum before cubes could be cast. This therefore confirmed that low w/s ratios lead to fast setting. Compressive strength results are shown in Fig. 8.

The following observations can be made from the results:

(a) The maximum strength obtained was about $60 \mathrm{MPa}$ for a paste proportion of $33 \%(\mathrm{C} 12, \mathrm{C} 14)$. It was observed that at the w/s ratio of $0.39(\mathrm{C} 13, \mathrm{C} 17$, $\mathrm{C} 19)$, the reduction in paste volume did not result in a significant strength reduction.

(b) w/s ratio effect on strength was moderate for values as high as 0.41 , and then the strength reduction was more pronounced.

(c) Slump fall with the investigated paste proportions was better controlled than during phase 1. Workability of produced concrete varied from very stiff (class S1) to very fluid (class S5) by changing w/s ratio and paste proportion (see Fig. 9).

\section{Discussion}

This study aimed at understanding the effects of paste proportion and w/s ratio on workability, setting time and strength development for a $60 \% / 40 \%$ pfa/ggbs-based
Fig. 5 a Slump measurements versus paste volume. b Compressive strength at 28 days versus paste volume. These contain the same data as shown in Figs. 3 and 4, which are presented differently highlighting the effects of paste volume (\%)
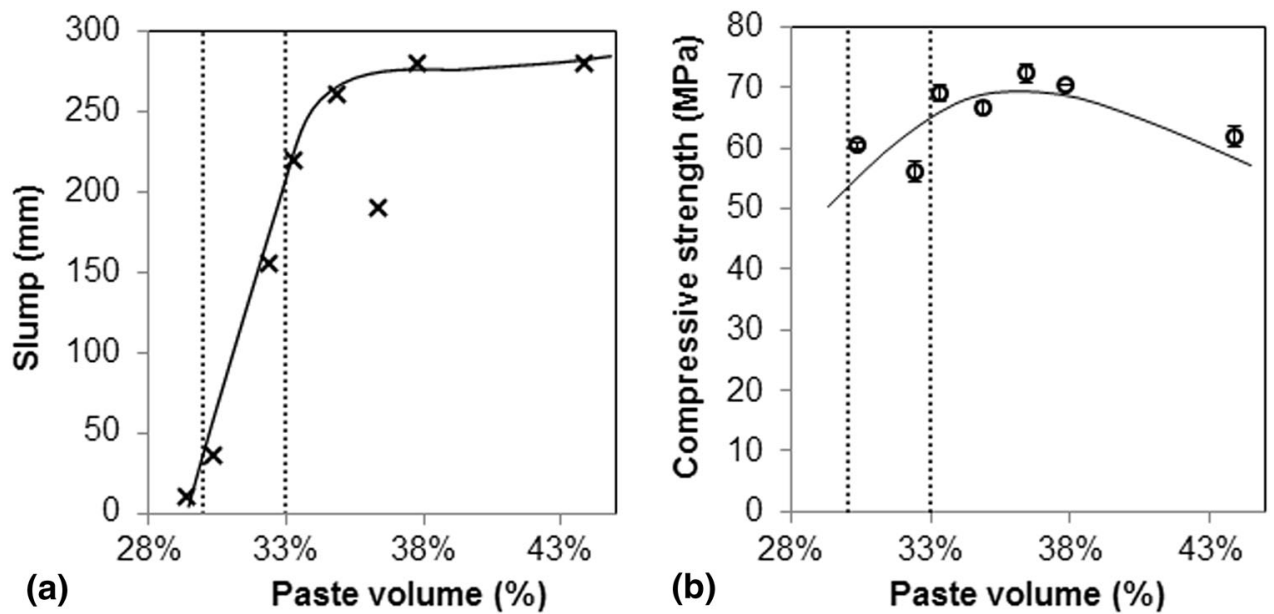


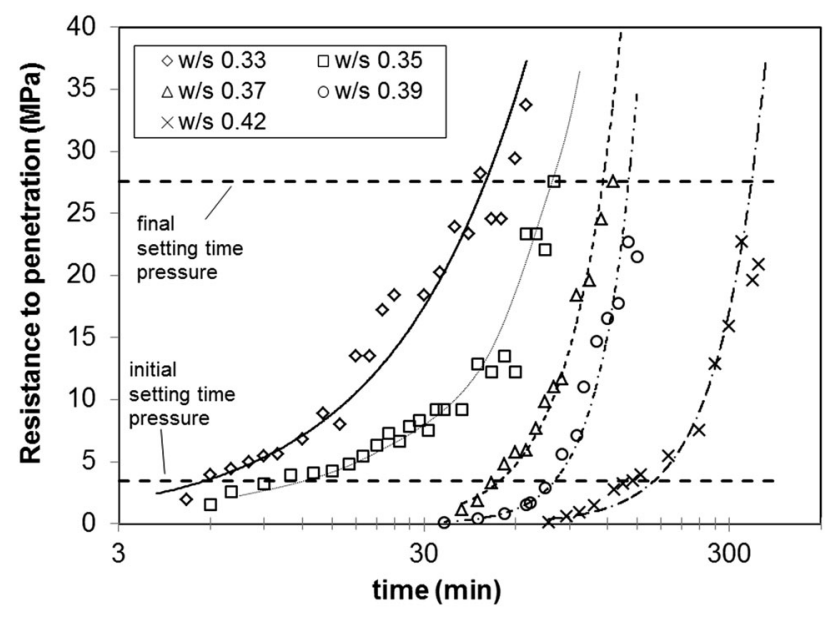

Fig. 6 Mortar penetration tests

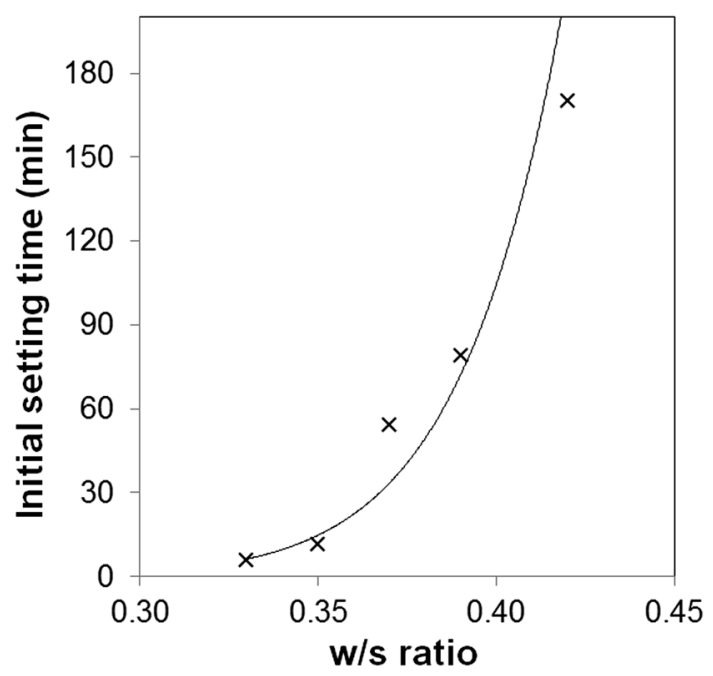

Fig. 7 Relationship between initial setting time and w/s ratio

alkali-activated concrete. It is known that also aggregate composition, inclusion of admixtures and activator dosages can have an influence on the physico-chemical properties of alkali-activated concrete, but these effects were out of the scope of this paper. The influence of paste proportion on workability was confirmed in the two phases of the study: paste proportion higher than $33 \%$ led to slump values greater than $200 \mathrm{~mm}$. The paste plays a role of a lubricant that depends on its viscosity and on the setting time: the more viscous the paste and the fastest the reaction, the smaller the slump. This result is confirmed by findings from literature: in [17], a binder content of $400 \mathrm{~kg} /$ $\mathrm{m}^{3}$ led to slump greater than $180 \mathrm{~mm}$, whereas in [26] a correlation was found between the slump and the paste/ aggregate ratio for $100 \%$ slag alkali-activated concrete with binder content higher than $450 \mathrm{~kg} / \mathrm{m}^{3}$. Compressive strength was also found to be influenced by the paste proportion, but the strength increment narrowed for binder content higher than $400 \mathrm{~kg} / \mathrm{m}^{3}$. This observation can also be found in [17].

Ggbs inclusion in the system allows the hardening of the concrete at room temperature (i.e. no need for thermal curing), but it can lead to fast setting, as reported also in [19]. W/s ratio was found to influence the setting time of the system: a direct relationship was found between the initial setting time and the w/s ratio. This delay of the reaction with the increase in w/s ratio was previously reported in ggbs activated with sodium silicate solution and was ascribed to the dilution effect of the activators [27]. W/s ratio also affects the strength development, but the behaviour of a pfa/ggbs blend differs from results on $100 \%$ pfa, where the reduction in strength with the increase in water content was found to be linear [9]. The presence of ggbs reduced the negative effects of water content increase, as reported also in [26]. The increase of the workability with higher w/s ratio was also observed, and it is presumably due to the lubricant effect of the water in the system, which affects the viscosity of the paste.

Visual inspection on crushed samples indicated that the bond between aggregates and binder matrix was stronger

Table 7 Phase 2 mix proportions, uniaxial compressive strength (UCS) and standard deviations (in bracket)

\begin{tabular}{llllllll}
\hline Label & Binder cont. $\left(\mathrm{kg} / \mathrm{m}^{3}\right)$ & w/s ratio & Paste volume $(\%)$ & UCS 1 day $(\mathrm{MPa})$ & UCS 7 days $(\mathrm{MPa})$ & UCS $28 \mathrm{days}(\mathrm{MPa})$ & Slump $(\mathrm{mm})$ \\
\hline $\mathrm{C} 11$ & 416 & 0.33 & 33 & - & - & - & - \\
$\mathrm{C} 12$ & 398 & 0.36 & 33 & $12.6(0.8)$ & $40.1(1.2)$ & $60.6(2.5)$ & 180 \\
$\mathrm{C} 13$ & 383 & 0.39 & 33 & $7.9(0.0)$ & $36.9(1.0)$ & $58.6(0.7)$ & 215 \\
$\mathrm{C} 14$ & 378 & 0.4 & 33 & $8.7(0.6)$ & $38.4(1.2)$ & $60.9(0.5)$ & 230 \\
$\mathrm{C} 15$ & 364 & 0.43 & 33 & $11.6(0.2)$ & $33.3(0.4)$ & $51.2(1.0)$ & 200 \\
$\mathrm{C} 16$ & 364 & 0.38 & 31 & $10.7(1.3)$ & $41.1(0.3)$ & $58.4(0.4)$ & 15 \\
$\mathrm{C} 17$ & 360 & 0.39 & 31 & $9.5(0.5)$ & $41.6(0.1)$ & $56.1(2.3)$ & 95 \\
$\mathrm{C} 18$ & 355 & 0.4 & 31 & $9.8(0.2)$ & $37.4(0.9)$ & $56.3(2.1)$ & 150 \\
$\mathrm{C} 19$ & 348 & 0.39 & 30 & $12.8(0.2)$ & $39.8(0.5)$ & $56.8(2.2)$ & 55 \\
$\mathrm{C} 20$ & 339 & 0.41 & 30 & $9.3(0.3)$ & $37(0.9)$ & $55.6(2.0)$ & 100 \\
$\mathrm{C} 21$ & 331 & 0.43 & 30 & $1.3(0.2)$ & $22.3(0.4)$ & $36.2(1.3)$ & 220 \\
\hline
\end{tabular}



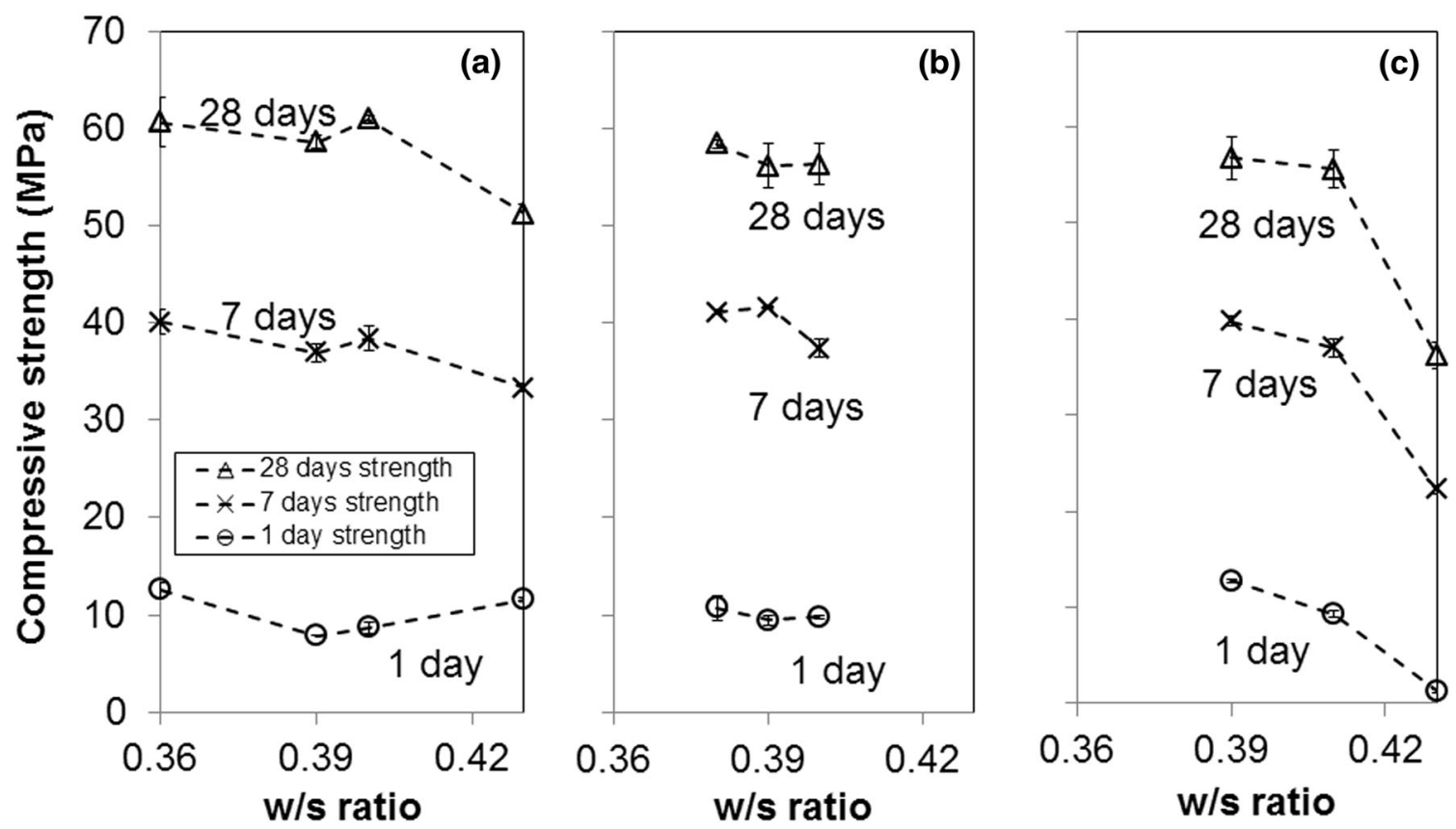

Fig. 8 Compressive strength versus w/s ratio. a $33 \%$ paste volume; b $31 \%$ paste volume; c $30 \%$ paste volume. Y axis for b and $\mathbf{c}$ is the same as a

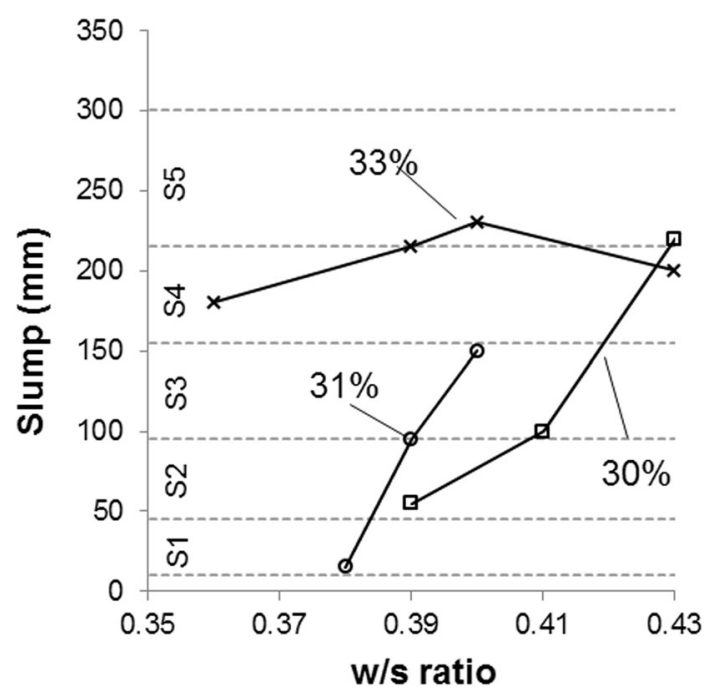

Fig. 9 Slump values measured for phase 2 concretes

for 28-day specimens compared to 1- and 7-day specimens: coarse particles were not easily detached from the matrix, fracture surfaces sometimes went through the aggregate and the failure was the typical double pyramid. 1- and 7-day samples did not show these failure patterns. There are suggestions [17] that the denser (compared to PC concrete) structure of the transition zone in AAC could be due to reduction of the porosity by the condensation of the excess $\mathrm{SiO}_{2}$ supplied by the activator, and to a potential reaction of the surfaces of siliceous aggregates with the alkali solution, forming additional reaction products around the aggregate particles for improved bond resulting in increased strengths.

A reduction in the paste content implies the reduction of binder and consequently the reduction of the quantity of activators (for fixed $\mathrm{M}+$ and $\mathrm{AM}$ ), because chemicals are dosed according to the binder mass. Chemical activators have been identified as being responsible for the main cost and environmental footprint of alkali-activated concrete [28]. Therefore, a reduction of paste proportion has positive implications in terms of cost and carbon footprint of the alkali-activated concrete. For the investigated binder blend, aggregate proportion and activator dosages, the paste proportion of $30 \mathrm{vol} \%$ can be considered sufficient for allowing a satisfactory development of compressive strength, with a variation of w/s ratio within the range $0.37-0.41$, where 0.37 was considered the minimum (in order to avoid fast initial setting) and 0.41 the maximum (in order to avoid high loss of strength). Other blends might require different ranges. Increasing the paste proportion may be necessary for achieving higher workability (slump $>100 \mathrm{~mm}$ ) without compromising the compressive strength.

\section{Conclusions}

In this study, mixes of $60 \%$ pfa and $40 \%$ ggbs were investigated for determining the effects of binder content, paste content and water-to-solid ratio on fresh and hardened properties of concrete. The investigation was carried out in two phases. In phase 1, a preliminary analysis of the effect of 
binder content on workability and strength development was carried out, with the aim of understanding the main trends and assessing preliminary desired values for fresh and hardened properties. In phase 2 , the optimisation of mix proportions was investigated, with the aim of controlling the workability without major impact on strength development.

The main conclusions from phase 1 are as follows:

(a) High binder contents (more than $400 \mathrm{~kg} / \mathrm{m}^{3}$ ) made it very difficult to control the workability, although compressive strengths up to $70 \mathrm{MPa}$ can be obtained with $450 \mathrm{~kg} / \mathrm{m}^{3}$.

(b) w/s ratio played a role in the setting time, and the relationship between w/s and initial setting time was determined for the investigated blend.

(c) w/s ratio does not affect significantly the strength development except for high values $(\geq 0.40)$.

(d) The reduction of paste volume had a moderate effect on the strength development.

Considering these outcomes, phase 2 was focused on low paste proportions $(\leq 33 \%)$ for determining the effect of w/s ratio both in terms of slump fall and of strength trends. It was concluded that:

(e) The development of fresh and hardened properties is controlled by the combined effects of paste proportion and w/s ratio.

(f) For the investigated binder composition (60/40 pfa/ ggbs), a paste proportion of $30 \%$ was found to be sufficient to achieve compressive strengths of around $57 \mathrm{MPa}$, with a w/s ratio within the range of $0.37-0.41$. The w/s ratio of 0.37 was considered to be the minimum that could be used to avoid fast initial setting of concrete. A w/s ratio higher than 0.41 would lead to significant strength reduction.

(g) A reduction in paste proportion has positive implications on the cost and on the environmental footprint of alkali-activated concrete. Increasing the paste proportion can achieve high workability (slump fall higher than $100 \mathrm{~mm}$ ) without compromising the compressive strength.

Acknowledgments This research was carried out in the framework of the SUS-CON "Sustainable, Innovative and Energy-Efficient Concrete, based on the Integration of All-Waste Materials" project, which has received funding from the European Union Seventh Framework Programme (FP7/2007-2013) under Grant Agreement No. 285463 (Call FP7-2011-NMP ENV-ENERGY-ICT-EeB).

\section{References}

1. CEMBUREAU (2015) The European Cement Association, key facts \& figures. http://www.cembureau.eu/about-cement/keyfacts-figures. Accessed 8 June 2015
2. United Nations Environment Program (2009) Buildings and climate change: Summary for Decision-Makers. http://www.unep. org/SBCI/pdfs/SBCI-BCCSummary.pdf. Accessed 11 June 2015

3. European Construction Industry Federation (2014) Key Figures 2014-activity 2013. http://www.fiec.eu/en/library-619/keyfigures.aspx. Accessed 11 June 2015

4. Olivier JG (2012) Trends in global $\mathrm{CO}_{2}$ emissions: 2012 Report. PBL Netherlands Environmental Assessment Agency, Hague

5. Provis J (2014) Green concrete or red herring? Future of alkali activated materials. Adv Appl Ceram 113(8):472-477. doi:10. 1179/1743676114Y.0000000177

6. Provis J, van Deventer J (2014) Alkali activated materials, stateof-the-art report, RILEM TC 224-AAM, Springer, Berlin

7. Van Deventer JSJ, Feng D, Duxson P (2010) Patent no. US7691198 B2

8. Kakebeeke PIJ, Keulen A (2013) Patent no. WO2013176545 A1

9. Joseph B, Mathew G (2012) Influence of aggregate content on the behavior of fly ash based geopolymer concrete. Sci Iranica A 19(5):1188-1194. doi:10.1016/j.scient.2012.07.006

10. Olivia M, Nikraz HR (2011) Strength and water penetrability of fly ash geopolymer concrete. J Eng Appl Sci 6(7):70-78

11. Sofi M, van Deventer JSJ, Mendis PA, Lukey GC (2007) Engineering properties of inorganic polymer concretes (IPCs). Cem Concr Res 37(2):251-257. doi:10.1016/j.cemconres.2006.10.008

12. Wongpa J, Kiattikomol K, Jaturapitakkul C, Chindaprasirt P (2010) Compressive strength, modulus of elasticity, and water permeability of inorganic polymer concrete. Mater Des 31(10):4748-4754. doi:10.1016/j.matdes.2010.05.012

13. Hardjito D, Wallah SE, Sumajouw DMJ, Rangan BV (2004) Factors influencing the compressive strength of fly ash-based geopolymer concrete. Civil Eng Dimens 6(2):88-93

14. Rangan BV, Sumajouw D, Wallah S, Hardjito D (2006) Reinforced low-calcium fly ash-based geopolymer concrete beams and columns. In: 31 st conference on our world in concrete \& structures, 16-17 August 2006, Singapore

15. Yost JR, Radlińska A, Ernst S, Salera M (2012) Structural behavior of alkali activated fly ash concrete. Part 1: mixture design, material properties and sample fabrication. Mater Struct 46(3):435-447. doi:10.1617/s11527-012-9919-x

16. Collins F, Sanjayan J (1999) Workability and mechanical properties of alkali activated slag concrete. Cem Concr Res 29:455-458. doi:10.1016/S0008-8846(98)00236-1

17. Bernal S, de Gutiérrez R, Pedraza A, Provis J, Rodriguez E, Delvasto S (2011) Effect of binder content on the performance of alkali-activated slag concretes. Cem Concr Res 41:1-8. doi:10. 1016/j.cemconres.2010.08.017

18. Lee N, Lee H (2013) Setting and mechanical properties of alkaliactivated fly ash/slag concrete manufactured at room temperature. Constr Build Mater 47:1201-1209. doi:10.1016/j.conbuildmat. 2013.05.107

19. Deb PS, Nath P, Sarker PK (2014) The effects of ground granulated blast-furnace slag blending with fly ash and activator content on the workability and strength properties of geopolymer concrete cured at ambient temperature. Mater Des 62:32-39. doi:10.1016/j.matdes.2014.05.001

20. Nath P, Sarker P (2014) Effect of GGBFS on setting, workability and early strength properties of fly ash geopolymer concrete cured in ambient condition. Constr Build Mater 66:163-171. doi:10.1016/j.conbuildmat.2014.05.080

21. Rajamane NP, Nataraja MC, Jeyalakshmi R, Nithiyanantham S (2015) Greener durable concretes through geopolymerisation of blast furnace slag. Mater Res Expr 2(5). doi:10.1088/2053-1591/2/5/ 055502

22. Luo X, Xu J, Li W, Bai E (2014) Effect of alkali-activator types on the dynamic compressive deformation behavior of geopolymer 
concrete. Mater Lett 124:310-312. doi:10.1016/j.matlet.2014.03. 102

23. Rafeet A, Vinai R, Sha W, Soutsos M (2014) Alkali activated fuel ash and slag mixes: optimization study from paste to concrete building blocks. In: 34th cement and concrete science conference, 14-17 September 2014, University of Sheffield (UK), pp 349-353

24. BS 1881-116 (1983) Testing concrete. Part 116: method for determination of compressive strength of concrete cubes

25. ASTM C403/C403M-08 (2008) Standard test method for time of setting of concrete mixtures by penetration resistance. ASTM International, West Conshohocken, PA
26. Hung CC, Chang JJ (2013) The influence of mixture variables for the alkali-activated slag concrete on the properties of concrete. J Mar Sci Technol 21(3):229-237. doi:10.6119/JMST-012-01094

27. Shi C, Day RL (1996) Some factors affecting early hydration of alkali-slag cements. Cem Concr Res 26(3):439-447. doi:10.1016/ S0008-8846(96)85031-9

28. Provis JL, Palomo A, Shi C (2015) Advances in understanding alkali-activated materials. Cem Concr Res 78(Part A):110-125. doi:10.1016/j.cemconres.2015.04.013 